\title{
OCCURRENCE AND FATE OF 17 $\beta$-ESTRADIOL IN WATER RESOURCES AND WASTEWATER IN AHVAZ, IRAN
}

\author{
HASSANI G. ${ }^{1,2}$ \\ BABAEI A.A. ${ }^{3,4}$ \\ TAKDASTAN A. ${ }^{3,4, *}$ \\ SHIRMARDI M. ${ }^{4}$ \\ YOUSEFIAN F. ${ }^{5}$ \\ MOHAMMADI M.J. ${ }^{6}$
}

\author{
${ }^{1}$ Social Determinants of Health Research Center \\ Yasuj University of Medical Sciences, Yasuj, Iran \\ ${ }^{2}$ Department of Environmental Health Engineering \\ Yasuj University of Medical Sciences, Yasuj, Iran \\ ${ }^{3}$ Environmental Technologies Research Center (ETRC) \\ Ahvaz Jundishapur University of Medical Sciences, Ahvaz, Iran \\ ${ }^{4}$ Department of Environmental Health Engineering \\ Ahvaz Jundishapur University of Medical Sciences, Ahvaz, Iran \\ ${ }^{5}$ Department of Environmental Health Engineering \\ Tehran University of Medical Sciences, Tehran, Iran \\ ${ }^{6}$ Abadan School of Medical Sciences, Abadan, Iran
}

Received: $16 / 06 / 2016$

Accepted: 26/09/2016

Available online: 02/11/2016

*to whom all correspondence should be addressed: e-mail: afshintakdastan@yahoo.com

\section{ABSTRACT}

Estradiol is known as the indicator of the presence of hormones as Endocrine Disruptor Compounds (EDCs) in water and wastewater. The entrance of these compounds into water resources through daily liquid wastes of societies as well as pharmaceutical industries, ranching, and pathology laboratories leads to an increase in their concentrations in these resources. Consequently, due to the metabolic properties of these substances they can cause adverse effects on consumers and aquatics. The main purpose of this research is to determine the occurrence and the fate of estradiol as indicator of endocrine-disrupting compounds in drinking water, surface water, and wastewater in Ahvaz, Iran. 17ß-estradiol was detected in $37.5 \%$ of samples obtained from drinking water and $68.75 \%$ of samples from the Karun River. In the urban drinking water and Karun River, the mean concentrations of $17 \beta$-estradiol were 2.96 and 13.66 $\mathrm{ng} \mathrm{l}^{-1}$, respectively.

In the domestic and industrial wastewater, the concentrations of $17 \beta$-estradiol were higher than that detected in the drinking and surface waters. The mean concentrations of this hormone in these wastewaters were 57.46 and $70.6 \mathrm{ng} \mathrm{l}^{-1}$, respectively. The highest amount of $17 \beta$-estradiol was measured in the hospital wastewater. The fate of $17 \beta$-estradiol in the slaughterhouse wastewater treatment plant, in which a septic tank, an anaerobic pond, and an aerobic tank were used for wastewater treatment, was higher than $75 \%$. The highest level of removal in the aerobic stage was also obtained by breaking estradiol down to other metabolites.

Keywords: estradiol, slaughterhouse wastewater, Ahvaz, Karun River, domestic wastewater

\section{Introduction}

Recently, disposal and discharge of solid, liquid and gas wastes into water resources have been increased drastically. These wastes include a wide range of natural and synthetic substances such as chemicals, medicines, human wastes, and dead or alive remains of human activities. One of the most important 
pollutants, which discharged to the environment, is Endocrine Disruptor Compounds (EDCs), which have attracted a lot of attention (Bhandari et al., 2014; Irwin et al., 2001). These compounds mainly include natural and synthetic steroid hormones and their derivatives, surfactants, chemical drugs and cosmetics (Caliman\& Gavrilescu, 2009). Due to their high environmental sustainability, their variety, their different effects at cellular and molecular levels, and their destructive physiological effects, these compounds require regular attention and control (Hamid\& Eskicioglu, 2012). The common hormones in this group of compounds include 17-alpha estradiol, 17-beta estradiol, estrone, estrogen, estriol, and ethinylestradiol (Purdom et al., 1994; Tyler et al., 2005). The adverse effects of these compounds include changes in sexual cycles and sexual behavior, negative effects on the immune system, abnormal sexual differentiation, tumor development, and cancer. Their most important negative effect is their participation in the development of cancer in hormonal areas of the body such as breasts, testis, and prostates. They also cause damages in utero and during infancy (Damstra et al., 2002). Discharge of these compounds into water resources leads to adverse effects on aquatic ecosystems and fishes. Damages to the reproductive cycle and spawning at the wrong times are two of the adverse effects of hormones on aquatics (Coe et al., 2010; Esplugas et al., 2007).

The 17-beta estradiol $\left(\mathrm{C}_{18} \mathrm{H}_{24} \mathrm{O}_{2}\right)$ hormone is among the most common steroid hormones with toxicity of approximately 1000 to 10000 times higher than that of Nonylphenol (Tanaka et al., 2001). This hormone is a sex hormone, which is at its highest levels in women and especially pregnant women. This hormone is responsible for the growth of breasts, proliferation of epithelium cells, and development of sexual characteristics (Havlíková et al., 2006). Every day 2.4 microgram of this hormone can be disposed through a woman's urine (Damstra et al., 2002). In addition, the average excretion of this hormone in men and pregnant women is more than $1.5 \mu \mathrm{g}$ per day and $259 \mu \mathrm{g}$ per day, respectively (Johnson et al., 2000; Sun and Zhou, 2014). The entrance of these compounds to water resources through daily liquid wastes of societies as well as pharmaceutical industries, ranching, and pathology laboratories leads to an increase in their concentrations in these resources. Consequently, due to the metabolic properties of these substances they can cause adverse effects on consumers and aquatics.

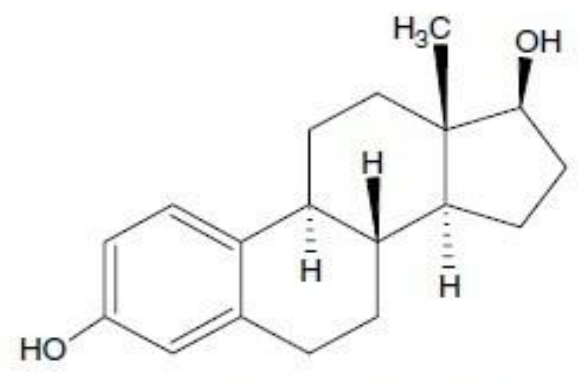

$17 \beta$-estradiol (E2)

Figure 1. Structure of the 17-beta estradiol hormone

Previous studies indicated that the amount of endocrine disruptor compounds in water resources as well as urban and industrial wastewater is increasing. In a study carried out in the Aveiro District in Portugal it was found out that the levels of estradiol were very high. It should be mentioned that the levels of this hormone in water and wastewater resources were between 0.03 and $200 \mathrm{\mu g} \mathrm{I}^{-1}$ (Silva et al., 2013). Moreover, the average concentrations of this hormone in the wastewater treatment plants in Ontario, Canada were $15.6 \mathrm{ng} \mathrm{l}^{-1}$ and $1.8 \mathrm{ng} \mathrm{l}^{-1}$ for the inflow and outflow, respectively (Servos et al., 2005). Regular examination of the levels of hormones in the inflow of different treatment plans in France also revealed the presence of the beta estradiol hormone with a concentration of 3.5 to $50 \mathrm{ng} \mathrm{l}^{-1}$ in all samples. Results of this study indicated that these compounds are present in the urban and rural wastewaters of this 
country (Gabet-Giraud et al., 2010). The presence of this hormone in hospital effluents is proved as well. Pauwels et al., reported a concentration of $16.9 \mathrm{ng} \mathrm{l}^{-1}$ for the estradiol hormone in the hospital effluents of the Gent City of Belgium (Pauwels et al., 2008). Although the efficiency rate of different wastewater treatment processes reflects a significant decrease in the concentrations of estradiol hormone in urban and industrial wastewaters, the insignificant concentration of this hormone in the effluents of treatment plants requires attention. Low concentration of this hormone results from the discharge of these effluents to surface and groundwater resources, the leakage of agricultural runoffs, and unauthorized disposal of urban wastewater into different water resources, especially rivers. These instances can leave negative effects on the lives of aquatics while this hormone can also cause risks if the effluent carrying it is meant to be reused. Research results indicated that the concentration of estrogen hormones in rivers receiving urban and industrial wastewaters is a lot higher than that of restricted rivers. For instance, the concentrations of estrone and estriol hormones in the Thames river, which receives wastewaters at different points, are more than 29 and $8 \mathrm{ng} \mathrm{l}^{-1}$, respectively (Lishman et al., 2006). Hence, the objective of the present study was to carry out quantitative and qualitative examinations of the estradiol hormone in different urban, industrial and hospital wastewaters, surface runoffs, the Karun River, which is the most important river in Khuzestan Province supplying drinking water distributed by the Water Distribution Network for Ahvaz population.

\section{Materials and Methods}

\subsection{The Study Area}

Ahvaz City is the capital of Khuzestan Province. This city has the latitude of $21^{\circ} 20^{\prime \prime} \mathrm{N}$ and the longitude of $48^{\circ} 40^{\prime \prime} \mathrm{E}$. It is located on a plain with an altitude of $18 \mathrm{~m}$. This city has an area of $20477 \mathrm{ha}$, which 6923 ha of it is being consumed by the urban context. The most important water resource in this city is the Karun River, which has a longitude of $48^{\circ} 15^{\prime \prime}-52^{\circ} 30^{\prime \prime} \mathrm{E}$ and a latitude of $30^{\circ} 17^{\prime \prime}-33^{\circ} 49^{\prime \prime} \mathrm{E}$ (Naddafi et al., 2007). As this river flows through different cities, a large volume of urban, industrial and hospital wastewaters pour into it. The average discharge of this river is $90 \mathrm{~m}^{3} \mathrm{sec}^{-1}$ in warm seasons and 2500 $\mathrm{m}^{3} \mathrm{sec}^{-1}$ in cold seasons with high levels of rainfall (Mojahedi and Attari, 2009).

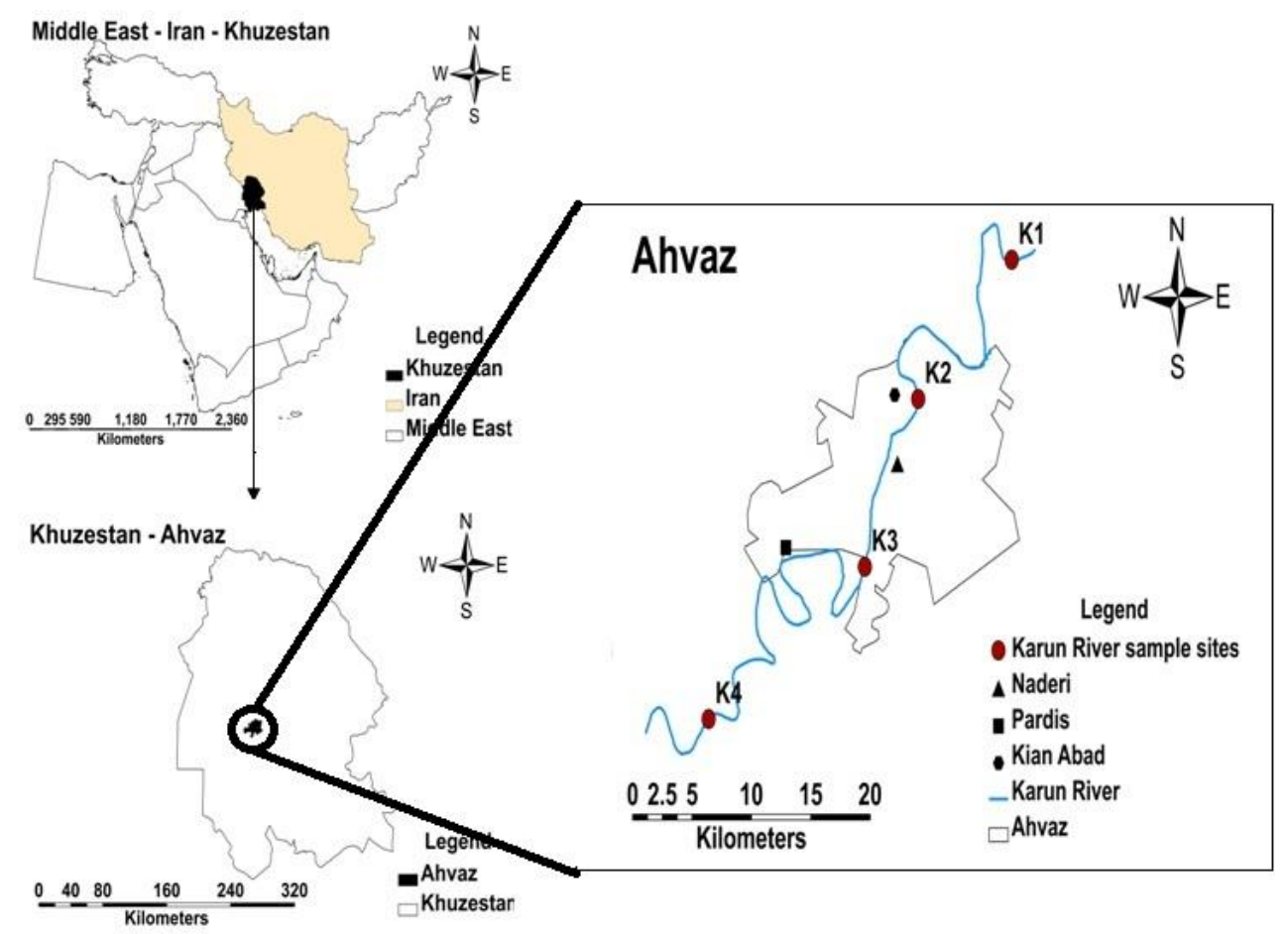

Figure 2. Sampling sites on the map of Ahvaz 
This river is a very important source of water in Khuzestan Province. Its water is used for different industrial demands as well as for agricultural and urban needs (Babaei et al., 2015). The drinking water for Ahvaz City is obtained from the Karun River. Water from this river enters a treatment plant and then flows into the distribution network. Areas used for collecting samples are shown on the map depicted in Figure 2.

\subsection{Sampling}

This study was conducted in 7 months. It involved 12 stages of sampling and lasted from May 2014 to December 2014. Water and wastewater samples were obtained from some marked areas of the Karun River in the course of sampling. Urban wastewater and hospital wastewater were also collected using dark 250-cc glass containers, which were stored at a temperature of $4{ }^{\circ} \mathrm{C}$. The samples were transferred to the laboratory after acquisition. The sampling areas were marked as follows based on the research objectives. Four points were marked along the Karun River: the first point was marked 5 kilometers to Ahvaz City; the fourth point was marked 10 kilometers after Ahvaz City; and the other two points were also marked along the river's path across Ahvaz City. Four points were selected for urban wastewaters and surface runoffs sampling. Three points were also selected in the drinking water distribution network as well as the point of harvest of urban drinking water. In order to estimate the content of estradiol in the hospital effluents, samples were obtained from the effluents discharged from the Imam Khomeini and Golestan hospitals in the course of research. Samples were also obtained from the wastewater produced by the slaughterhouse in Ahvaz City using the following 6 sources: raw water, septic input, anaerobic pond input, anaerobic process input, treatment plant output, and water resources adjacent to the place where the effluent was discharged.

\subsection{Analysis Method}

The concentrations of estradiol in the samples were determined using different methods based on the possible concentrations predicted for water resources. Samples obtained from the Karun River and the urban water distribution network were examined through ELISA method (Silva et al., 2013), a Hiperion NP4 plus Elisa Reader and GmbH and IBL assay kits made in Germany were used. The concentration of hormones in samples obtained from the raw wastewater and slaughterhouse effluents were measured using the Electrochemiluminescence by Elecsis 200 (Hitachi, Japan) and E2 || kit (Hitachi, Japan).

\section{Results and Discussion}

\subsection{Concentration levels of Estradiol in Drinking Water of Ahvaz City}

Raw water samples were collected from a basin before the treatment plant to measure the levels of estradiol. The source of drinking water for Ahvaz City is the Karun River and water from this river enters the distribution network following treatment. Results of analyses of samples obtained from July 2014 to December 2014 showed that the concentration of estradiol varied between 5.4 and $7.7 \mathrm{ng} \mathrm{l}^{-1}$. According to the results, estradiol existed in $37.5 \%$ of samples obtained from the distribution network. The average concentration of this hormone in the distribution network was also $2.96 \mathrm{ng} \mathrm{l}^{-1}$, which is higher than that previously reported in the literature (Benotti et al., 2008; Kuch and Ballschmiter, 2001). Seemingly, with an increase in the distance from the water treatment plant as well as the distance transferred by water in the distribution network, the concentration of estradiol increases due to the following reasons: leakage of urban and industrial wastewater; the high level of groundwater resources; the possibility of entrance of chemicals and hormones into the water pipes through human urine and excrements, household wastes, and medicines (Manickum\& John, 2014). In 7 of the 8 stages of obtaining samples from Kian Abad station of the urban water distribution network, the concentrations of estradiol were insignificant. It is worth noting that the very trace concentrations could not be measured using the measuring methods used in this research. However, in 5 of the 8 samples obtained from Pardis Station, which has a longer distance from the water treatment plant and thus receives water after a longer time, the concentrations of estradiol could be measured. The average concentration of estradiol in these samples was $2.92 \mathrm{ng} \mathrm{I}^{-1}$. 
Results showed lower concentrations compared to the results reported by Nie et al., (2014). Due to the lack of an acceptable standard for the concentration of estradiol and since this hormone is classified as a CCL3 (Contaminant Candidate List 3) compound by the US Environmental Protection Agency (US.EPA, 2014), it is necessary to minimize the concentration of this hormone in the distribution network using different treatment and regular examination methods. The objective is to minimize different risks associated with contacting and drinking this hormone.

\subsection{Concentration of Estradiol in the Karun River}

According to the results of examinations aimed to measure the levels of EDCs, the level of estradiol in the samples was high. Table 1 shows the concentrations of estradiol in different samples obtained from the Karun River. As seen in this table, the concentration of this hormone increases as the water of this river passes through Ahvaz city. This considerable increase can be ascribed to the targeted unauthorized discharge of urban and industrial wastewaters. In $31.25 \%$ of the samples, the concentrations of estradiol were not measurable. The total average concentration of estradiol in Station K4, which is located 10 kilometers to Ahvaz City, was $13.66 \mathrm{ng} \mathrm{l}^{-1}$. This value is almost higher than the results obtained for other world rivers (Johnson et al., 2000; Writer et al., 2011). Table 2 shows the concentrations of estradiol in other world rivers. These figures were obtained through different separate studies. The results of this research suggest that the concentration of estradiol in the Karun River is much lower than the concentration of this hormone in the southern rivers of Jiangsu Province in China (Yuan et al., 2014). It is worth noting that the average concentration of estradiol in the sampling areas of Ahvaz City and Jiangsu Province was $13.66 \mathrm{ng} \mathrm{l}^{-1}$ and $52.71 \mathrm{ng} \mathrm{l}^{-1}$, respectively. However, the concentration of this hormone in the Karun River is higher than the results obtained for five rivers in the Queensland State of the United States (Ying et al., 2009). Hence, it seems that the increase in the concentrations of this hormone in the surface waters of developed countries can be ascribed to the lack of proper management of urban and industrial wastewaters and the uncontrolled discharge of these wastewaters into water resources.

Table 1. Concentration level of 17- $\beta$ estradiol in Karun River at different sample sites

\begin{tabular}{cccccccccc}
\hline & July & August & September & October & October & November & November & December & Average \\
\hline K1 & ND & ND & 5.6 & 6.2 & 5.4 & ND & 6 & 4.7 & 5.58 \\
\hline K2 & 7.6 & 6.4 & 6.8 & 8.7 & 9.6 & ND & 8.9 & 7.6 & 7.94 \\
\hline K3 & 11 & 9.7 & ND & 11.6 & 12.4 & ND & ND & 10.3 & 11 \\
\hline K4 & 12.4 & 13.7 & ND & 12.9 & ND & 14.5 & ND & 14.8 & 13.66 \\
\hline
\end{tabular}

Results indicated that with a decrease in air temperature and with the onset of autumn, the concentration of estradiol in the Karun River escalates. This can be explained by the reduction in chemical interactions as well as biological processes, which eventually leads to a decrease in the breakdown of estradiol (Zhao et al., 2006). On the other hand, the increase in the concentration of estradiol over time can be ascribed to a reduction in the discharge of the river water because with a decrease in the discharge the rate of selfpurification and rarefaction increases. This increase consequently leads to an increase in the concentration of pollutants. The highest concentration of estradiol recorded for the Karun River was 14.8 $\mathrm{ng} \mathrm{I}^{-1}$ which was recorded in December in the K4 sampling station.

Table 2. Concentration level of $17-\beta$ estradiol in different rivers of world

\begin{tabular}{cccc}
\hline River & Country & E2 concentration $\left(\mathbf{n g} \mathbf{I}^{-\mathbf{1}}\right)$ & Reference \\
\hline Jiulongjiang River & China & 52.71 & (Yuan et al., 2014) \\
\hline River Arun & England & 0.6 & (Peck et al., 2004) \\
\hline River Ouse & England & 0.6 & (Peck et al., 2004) \\
\hline Rivers in Tianjin & China & $1.87-11.5$ & (Rao et al., 2013) \\
\hline Dan-Shui River & Taiwan & $1.4-33.9$ & (Zhang et al., 2014) \\
\hline Dutch surface water & Netherlands & $0.3-7.2$ & (Zhang et al., 2014) \\
\hline Redwood River & USA & 0.96 & (Writer et al., 2011) \\
\hline Jalle d'Eysines & France & 4.4 & (Labadie and Budzinski, 2005) \\
\hline
\end{tabular}




\subsection{Concentration of Estradiol in domestic wastewater}

The levels of estradiol in all of the samples obtained from the untreated wastewater of Ahvaz City were measureable. The average concentration of estradiol in the wastewater treatment plant input was 57.46 $\mathrm{ng} \mathrm{l}^{-1}$. The most important source of the entrance of estradiol into domestic wastewater is human urine, which is disposed on a daily basis. Estradiol is known as the indicator of the presence of EDCs in wastewaters. Therefore, numerous studies have been carried out on the control and measurement of this hormone. Measurements of the concentration of this hormone in the urban wastewater of Ahvaz City indicated that the concentration of this hormone is high in this city. The overall characteristics of the wastewater produced by Ahvaz City are shown in brief in Table 3. This wastewater is composed of human wastes, industrial wastewater, wastewater produced by small-scale workshops, and runoffs.

Table 3. Qualitative characteristics of Ahvaz domestic wastewater

\begin{tabular}{|c|c|c|c|c|c|}
\hline pH & BOD $\left(\mathrm{mg} \mathrm{l}^{-1}\right)$ & $\operatorname{COD}\left(\mathrm{mg} \mathrm{l}^{-1}\right)$ & TSS $\left(\mathrm{mg} \mathrm{l}^{-1}\right)$ & Total $\mathbf{P}\left(\mathrm{mg} \mathrm{l}^{-1}\right)$ & Total $\mathbf{N}\left(\mathrm{mg} \mathrm{l}^{-1}\right)$ \\
\hline 7.3 & 189 & 314 & 310 & 5.7 & 49 \\
\hline
\end{tabular}

As the distance from the treatment plant and ending points of the wastewater collection system reduces, wastewater discharge increases, and consequently the concentration of estradiol rises slightly. The high concentration of suspended solids in the urban wastewater provides a great opportunity for the absorption of pollutants and organic compounds. Due to its high absorption properties, estradiol tends to be absorbed by solids, which settle at stagnant points or at areas where the velocity of the wastewater flow is very low. Therefore, the aforementioned solids leave the wastewater flow through settlement (Koh et al., 2008). Breakdown of estradiol into its intermediate compounds or metabolites such as estrone (E1) and 17-alpha estriol (E3) can reduce its concentration at the end of the wastewater system (Hashimoto et al., 2007).

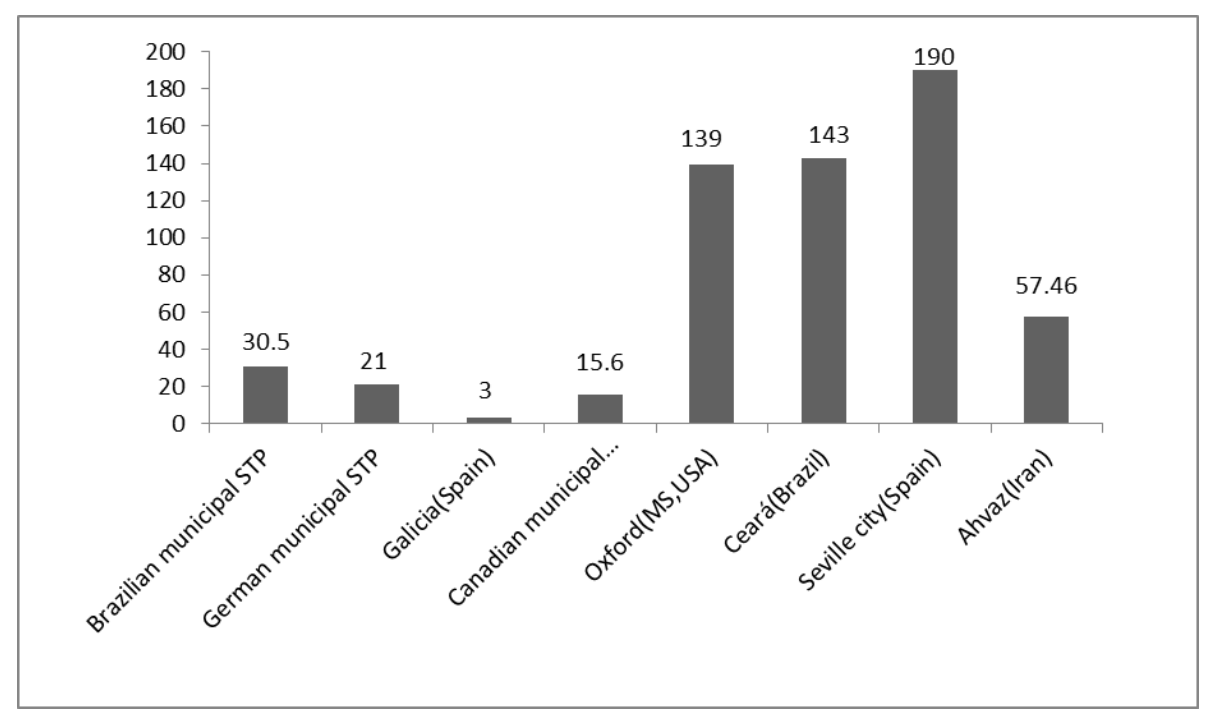

Figure 3. Average levels of estradiol in different municipal wastewater

However, the discharge of wastewaters containing high concentrations of estradiol, effluents of pathology laboratories and different industries such as the pharmaceutical industry, increased the levels of this hormone. The concentrations of this hormone in the urban wastewater produced in Ahvaz City varied between 31.3 and $69.4 \mathrm{ng} \mathrm{l}^{-1}$. The lowest concentration was recorded in July for runoffs discharging into the wastewater system while the highest concentration was observed in the input of the wastewater treatment plant in October. The insignificant transformation of estrone into estradiol in anaerobic conditions caused by the use of the existing oxygen by microorganisms in the wastewater can also contribute to the increase in the concentration of estradiol at the ending points of the wastewater collection system (Ren et al., 2007). Figure 3 shows the average levels of estradiol reported by different 
studies from all over the world (Carballa et al., 2004; Martín et al., 2012; Pessoa et al., 2014; Servos et al., 2005; Ternes et al., 1999; Tilton et al., 2002).

\subsection{Concentration of Estradiol in Hospital wastewater}

Based on the results, the amount of wastewater produced by Iranian hospitals is 400 to 1100 liter per bed per day (Mesdaghinia et al., 2009; Sarafraz et al., 2007). Hospital wastewaters contain a wide range of toxic chemical pollutants, antibiotics, hormones, heavy metals, and radioactive substances (Suarez et al., 2009). All of the samples obtained from the wastewater of the hospitals under study contained a high level of estradiol. The average concentration of estradiol recorded for Golestan and Imam Khomeini hospitals of Ahvaz City during the study was 93.53 and $83.22 \mathrm{ng} \mathrm{l}^{-1}$, respectively. Figure 4 shows different concentrations of estradiol from July 2014 to December 2014. As seen in this figure, the concentration of estradiol in the effluent of Golestan Hospital is slightly higher than that of Imam Khomeini Hospital. The quality of hospital wastewaters is determined by the number of patients, geographical location and climatic conditions, which cause changes to the concentration of different types of pollutants. The wastewater produced by the hospitals under study is discharged either directly or indirectly into the surface water resources of the city, namely the Karun River after being treated by hospitals wastewater treatment plants. The higher concentration of estradiol in the hospital wastewaters compared to the urban wastewaters can be ascribed to the use of drugs containing sex hormones in different hospital units, higher disposal of human wastewater, such as urine and blood due to the high population density, the higher number of pregnant women, and the operation of the labor units in hospitals (Pauwels\& Verstraete, 2006; Suarez et al., 2009). The higher concentration resulted from the present research compared to the concentration reported by Pauwels et al., can be explained by the discharge of pharmaceutical wastes and drugs as well as unused hormones into wastewaters, structural differences, and the type of services provided in hospitals (Pauwels et al., 2008).

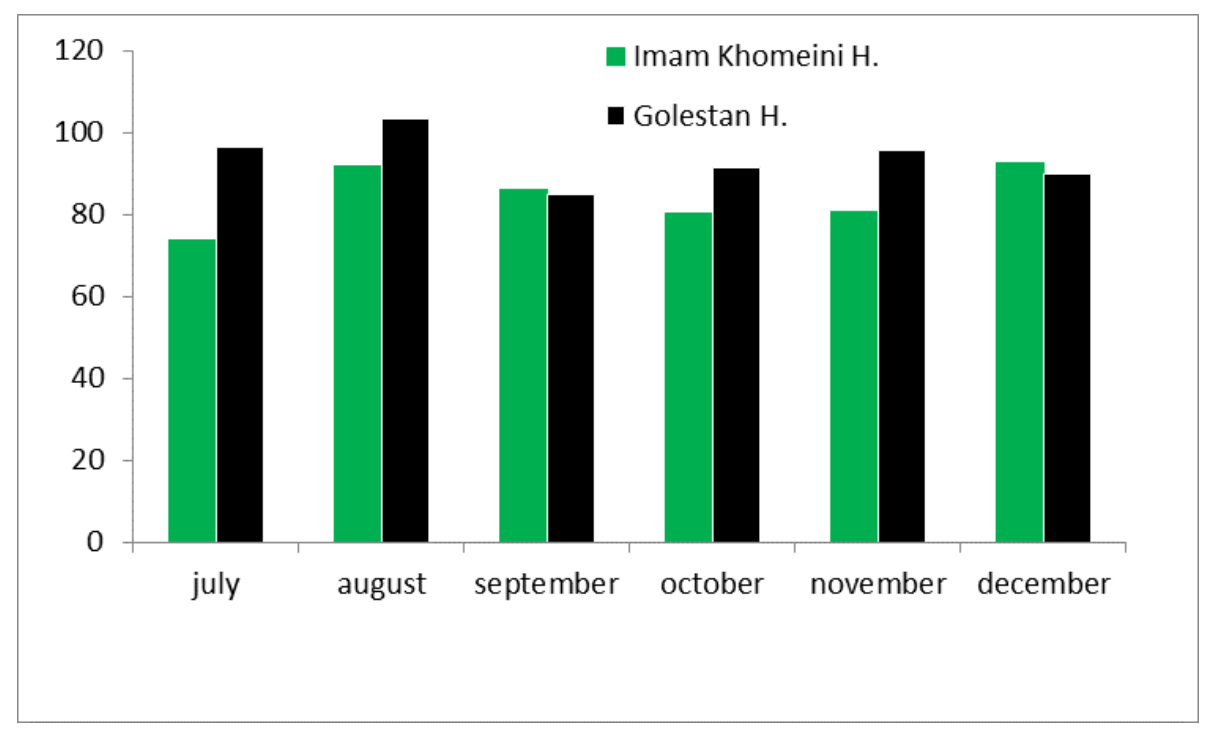

Figure 4. Concentration of Estradiol in Hospital wastewater in sampling period

\subsection{Occurrence and fate of Estradiol in the Slaughterhouse Wastewater}

Slaughter and cleaning of livestock in slaughterhouses lead to the discharge of different pollutants and micro pollutants into the wastewater cycle. These pollutants include a wide range of organic substances present in liquid and solid wastes produced by cleaning corpses of animals and their body contents. Natural and synthetic hormones in the body of animals find their way to the wastewater system through these wastes. Results of the present study indicated that the levels of estradiol in the wastewater of the slaughterhouse in Ahvaz City are high. The average concentration of estradiol in the wastewater of this slaughterhouse from May 2014 to November 2014 was $70.6 \pm 16.98 \mathrm{ng}^{-1}$. The maximum concentration 
of estradiol in the studied samples was $98.3 \mathrm{ng} \mathrm{l}^{-1}$, which was recorded in November and belonged to the raw wastewater entering the treatment plant.

The slaughterhouse wastewater is entered to a wastewater treatment plant, which includes a septic pond, which is mainly responsible for equalization and preserving the input, followed by an anaerobic pond, an anaerobic pond, and an activated sludge treatment system. Analysis of the qualitative properties of the resulting wastewater revealed the high concentrations of pollutants in the wastewater. Although the existing treatment plant is highly productive in omitting different pollutants and reducing the levels of qualitative parameters of the input wastewater, the effluent produced by the treatment plant contains a high level of pollutants, which reduces the quality of the effluent resulting to the lower quality of the untreated urban wastewater. Figure 5 shows the levels of BOD, COD, pH, TSS, TKN, oil and fat in the input of the treatment plant as well as its treated effluent. As seen in this figure, the removal rate of COD and BOD is approximately $90.7 \%$ and $90.8 \%$, respectively. In addition, the $\mathrm{pH}$ of the wastewater entering the slaughter wastewater treatment plant is 7.9 , while the $\mathrm{pH}$ of the effluent leaving the treatment plant is 7.5 due to an increase in the acidity of the wastewater.

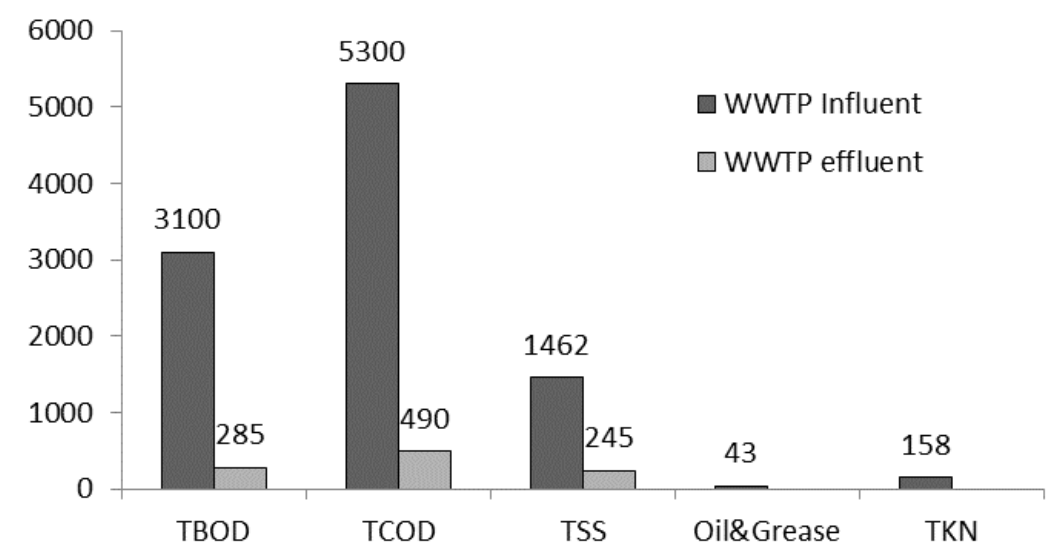

Figure 5. Removal efficiency of various qualitative parameters in Ahvaz slaughterhouse wastewater treatment plant

Levels of estradiol were measured in different phases of the treatment plant from May 2014 to November 2014 through 11 steps.

Table 4. Occurrence of estradiol in specified sites of slaughterhouse wastewater treatment plant

\begin{tabular}{|c|c|c|c|c|c|c|c|c|c|c|c|}
\hline & May & May & June & June & July & August & September & October & October & November & November \\
\hline Raw water & ND & 6.2 & 2.8 & 3.7 & ND & 4.4 & ND & ND & 6 & 3.2 & 5 \\
\hline $\begin{array}{l}\text { septic } \\
\text { influent }\end{array}$ & 64.5 & 74.8 & 81.9 & 42.5 & 88.4 & 53 & 53.8 & 64.1 & 70.9 & 98.3 & 84.5 \\
\hline $\begin{array}{l}\text { Anaerobic } \\
\text { tank } \\
\text { influent }\end{array}$ & 58.4 & 63.7 & 75 & 36.5 & 80.6 & 46.8 & 47.6 & 56 & 63.5 & 90 & 69.2 \\
\hline $\begin{array}{l}\text { Aerobic } \\
\text { tank } \\
\text { effluent }\end{array}$ & 43.2 & 48.5 & 56 & 26.4 & 69.8 & 40.1 & 41.7 & 43.6 & 46.2 & 74.6 & 54.5 \\
\hline $\begin{array}{l}\text { WWTP } \\
\text { influent }\end{array}$ & 20.2 & 17.5 & 18.6 & 8.9 & 15.9 & 13.5 & 13.6 & 16.8 & 21.5 & 23.3 & 19.8 \\
\hline $\begin{array}{l}\text { Water } \\
\text { resources }\end{array}$ & 14.2 & 13.5 & 14.5 & 8.6 & 14.2 & 13.4 & 13 & 12.5 & 14.8 & 14 & 13.6 \\
\hline
\end{tabular}


In May, June, October, and November two sampling rounds were completed while in other months one sampling round was completed. The sources of sampling include raw water, septic pond input, anaerobic pond input, aerobic pond input, and treatment plant effluent.

Table 4 shows the levels of estradiol recorded for the samples through 11 phases of sampling. The total average rate of removal of estradiol in the treatment plant over 7 months was $75.38 \pm 3.82 \%$, which is lower than the figure reported by Servos et al., (2005) Seemingly, with an increase in the sludge retention time and duration of aeration process, the amount of estradiol removed in the treatment plant and especially in the aerobic pond can be increased (Hashimoto et al., 2007; Ifelebuegu, 2011). The aerobic process used for treating slaughterhouse wastewater yielded the highest rate of removal of estradiol from the input wastewater. The average rate of estradiol removal through the aerobic process was $64.41 \pm 6.77 \%$. The anaerobic pond and septic tank demonstrate average removal rate of $20.97 \pm 5.73$ and $11.68 \pm 3.06 \%$, respectively. Considering different processes employed for the removal of estrogen hormones from wastewater in the anaerobic stages, it can be said that the major removal was obtained by inhibiting the surface absorption of estradiol by solids, which were prone to sedimentation, and lightweight floating materials. The highest level of removal in the aerobic stage was also obtained by breaking estradiol down to other metabolites.

Regular monitoring of groundwater and surface water resources near the treatment plant revealed an increase in the concentration of estradiol in these water resources. The concentration of estradiol in the water resources near the slaughterhouse and the wastewater treatment plant varied between 8.6 and $14.8 \mathrm{ng} \mathrm{l}^{-1}$ with an average level of $13.3 \pm 1.69 \mathrm{ng} \mathrm{l}^{-1}$.

\section{Conclusion}

The presence of estrogen hormones such as estradiol in different water resources as well as urban and industrial wastewaters is undeniable. Due to the reported complications and physiological disorders, it is necessary to control and measure the levels of hormones in water resources on a regular basis. The present study was an attempt to measure the levels of estradiol in different water resources such as the drinking water in the distribution network, the water of the Karun River, urban wastewater, hospital wastewater, and slaughterhouse wastewater as an industrial effluent. Samples were collected within 6 to 8 months and through 8 to 11 phases, which lasted from May 2014 to December 2014. Samples were obtained from 20 points of the aforementioned sources. A total of 162 samples were analyzed in this study. In all of the samples obtained from urban, hospital and slaughterhouse wastewaters, $68.75 \%$ of the samples obtained from the Karun River, and $37.5 \%$ of the samples obtained from the urban water distribution network the levels of estradiol were measureable with average amounts of 57.46, 83-93, 70.6, 13.66 and $2.96 \mathrm{ng} \mathrm{l}^{\mathrm{I}^{-1}}$, respectively.

The Karun River, as the largest river in the southwest of Iran, contains a high level of contamination due to the discharge of untreated urban and industrial wastewaters. It is possible to prevent further contamination of this river by controlling the unauthorized discharge of urban and industrial effluents, establishing the necessary treatment plants in urban areas and near-river industrial sites, and improving treatment processes in the existing treatment plants. The total removal rate of estradiol in the wastewater treatment plant for the slaughterhouse in Ahvaz City is $75 \%$. Since $64 \%$ of this figure is explained by aerobic processes while $21 \%$ belongs to anaerobic processes, it is concluded that aerobic processes are more effective in removing this hormone from the wastewater system. Finally, considering the adverse effects of estrogen hormones on the consumers and living beings (especially aquatics), it is necessary to measure the concentrations of other natural and synthetic hormones in different water resources of Ahvaz City to prevent their possible threats.

\section{Acknowledgements}

The authors are grateful to the Environmental Technologies Research Center, Ahvaz Jundishapur University of Medical Sciences for supporting this research (grant No: ETRC9305). We also express our gratefulness for the 
assistances provided by the Iran Zamin Laboratory and Mr. Ahmadipour, the head of the slaughterhouse treatment plant in Ahvaz.

\section{References}

Babaei A.A., Alavi N., Hassani G., Yousefian F., Shirmardi M. and Atari L.(2015), Occurrence and related risk assessment of trihalomethanes in drinking water, Ahvaz, Iran, Fresenius Environmental Bulletin, 24(12C), 4807-4815.

Benotti M.J., Trenholm R.A., Vanderford B.J., Holady J.C., Stanford B.D. and Snyder S.A. (2008), Pharmaceuticals and endocrine disrupting compounds in US drinking water, Environmental Science \& Technology, 43(3), 597-603.

Bhandari R.K., Deem S.L., Holliday D.K., Jandegian C.M., Kassotis C.D., Nagel S.C., Tillitt D.E., vom Saal F.S. and Rosenfeld C.S. (2015), Effects of the environmental estrogenic contaminants bisphenol A and $17 \alpha$-ethinyl estradiol on sexual development and adult behaviors in aquatic wildlife species, General and Comparative Endocrinology, 214, 195-219.

Caliman F.A.and Gavrilescu M. (2009), Pharmaceuticals, personal care products and endocrine disrupting agents in the environment-a review, CLEAN-Soil, Air, Water, 37, 4-5, 277-303.

Carballa M., Omil F., Lema J.M., Llompart M., García-Jares C., Rodríguez I., Gómez M. and Ternes T. (2004), Behavior of pharmaceuticals, cosmetics and hormones in a sewage treatment plant, Water Research, 38(12), 2918-2926.

Coe T. S., Söffker M.K., Filby A.L., Hodgson D. and Tyler C.R. (2010), Impacts of early life exposure to estrogen on subsequent breeding behavior and reproductive success in zebrafish, Environmental Science and Technology, 44, 16, 6481-6487.

Damstra T., Barlow S., Bergman A., Kavlock R. and van der Kraak G. (2002), Global assessment of the state-of-thescience of endocrine disruptors, Geneva: World Health Organization

Esplugas S., Bila D.M., Krause L.G.T. and Dezotti M. (2007), Ozonation and advanced oxidation technologies to remove endocrine disrupting chemicals (EDCs) and pharmaceuticals and personal care products (PPCPS) in water effluents, Journal of Hazardous Materials, 149(3), 631-642.

Gabet-Giraud V., Miège C., Choubert J.M., Ruel S.M. and Coquery M. (2010), Occurrence and removal of estrogens and beta blockers by various processes in wastewater treatment plants, Science of the Total Environment, 408(19), 4257-4269.

Hamid H.and Eskicioglu C. (2012), Fate of estrogenic hormones in wastewater and sludge treatment: A review of properties and analytical detection techniques in sludge matrix, Water Research, 46(18), 5813-5833.

Hashimoto T., Onda K., Nakamura Y., Tada K., Miya A. and Murakami T. (2007), Comparison of natural estrogen removal efficiency in the conventional activated sludge process and the oxidation ditch process, Water Research, 41(10), 2117-2126.

Havlíková L., Nováková L., Matysová L., Sicha J. and Solich P. (2006), Determination of estradiol and its degradation products by liquid chromatography, Journal of Chromatography A, 1119(1), 216-223.

Ifelebuegu A. (2011), The fate and behavior of selected endocrine disrupting chemicals in full scale wastewater and sludge treatment unit processes, International Journal of Environmental Science and Technology, 8, 245-254.

Irwin L. K., Gray S.and Oberdörster E. (2001), Vitellogenin induction in painted turtle, Chrysemys picta, as a biomarker of exposure to environmental levels of estradiol, Aquatic Toxicology, 55(1), 49-60.

Johnson A., Belfroid A. and Di Corcia A. (2000), Estimating steroid oestrogen inputs into activated sludge treatment works and observations on their removal from the effluent, Science of the Total Environment, 256(2), 163-173.

Koh Y.K., Chiu T.Y., Boobis A., Cartmell E., Scrimshaw M.D. and Lester J.N. (2008), Treatment and removal strategies for estrogens from wastewater, Environmental Technology, 29(3), 245-267.

Kuch H. M.and Ballschmiter K. (2001), Determination of endocrine-disrupting phenolic compounds and estrogens in surface and drinking water by HRGC-(NCl)-MS in the picogram per liter range, Environmental Science and Technology, 35(15), 3201-3206.

Labadie P.and Budzinski H. (2005), Determination of steroidal hormone profiles along the Jalle d'Eysines River (near Bordeaux, France), Environmental Science and Technology, 39(14), 5113-5120. 
Lishman L., Smyth S.A., Sarafin K., Kleywegt S., Toito J., Peart T., Lee B., Servos M., Beland M. and Seto P. (2006), Occurrence and reductions of pharmaceuticals and personal care products and estrogens by municipal wastewater treatment plants in Ontario, Canada, Science of the Total Environment, 367(2), 544-558.

Manickum T. and John W. (2014), Occurrence, fate and environmental risk assessment of endocrine disrupting compounds at the wastewater treatment works in Pietermaritzburg (South Africa), Science of the Total Environment, 468-469, 584-597.

Martín J., Camacho-Muñoz D., Santos J.L., Aparicio I. and Alonso E. (2012), Occurrence of pharmaceutical compounds in wastewater and sludge from wastewater treatment plants: removal and ecotoxicological impact of wastewater discharges and sludge disposal, Journal of Hazardous Materials, 239, 40-47.

Mesdaghinia A., Naddafi K., Nabizadeh R., Saeedi R. and Zamanzadeh M. (2009), Wastewater characteristics and appropriate method for wastewater management in the hospitals, Iranian Journal of Public Health, 38(1), 34-40.

Mojahedi S.A. and Attari J. (2009), A Comparative Study of Water Quality Indices for Karun River. Paper presented at the World Environmental and Water Resources Congress 2009@ sGreat Rivers.

Naddafi K., Honari H. and Ahmadi M. (2007), Water quality trend analysis for the Karoon River in Iran, Environmental Monitoring and Assessment, 134(1-3), 305-312.

Nie M., Yang Y., Liu M., Yan C., Shi H., Dong W. and Zhou J.L. (2014), Environmental estrogens in a drinking water reservoir area in Shanghai: Occurrence, colloidal contribution and risk assessment, Science of the Total Environment, 487, 785-791.

Pauwels B., Noppe H., De Brabander H. and Verstraete W. (2008), Comparison of steroid hormone concentrations in domestic and hospital wastewater treatment plants, Journal of Environmental Engineering, 134(11), 933-936.

Pauwels B.and Verstraete W. (2006), The treatment of hospital wastewater: an appraisal, Journal of Water and Health, 4, 405-416.

Peck M., Gibson R.W., Kortenkamp A. and Hill E.M. (2004), Sediments are major sinks of steroidal estrogens in two United Kingdom rivers, Environmental Toxicology and Chemistry, 23(4), 945-952.

Pessoa G.P., de Souza N.C., Vidal C.B., Alves J.A.C., Firmino P.I.M., Nascimento R.F. and dos Santos A.B. (2014), Occurrence and removal of estrogens in Brazilian wastewater treatment plants, Science of the Total Environment, 490, 288-295.

Purdom C., Hardiman P.A., Bye V.V.J., Eno N.C., Tyler C.R. and Sumpter J.P. (1994), Estrogenic effects of effluents from sewage treatment works, Chemistry and Ecology, 8(4), 275-285.

Rao K., Lei B., Li N., Ma M. and Wang Z. (2013), Determination of estrogens and estrogenic activities in water from three rivers in Tianjin, China, Journal of Environmental Sciences, 25(6), 1164-1171.

Ren Y.-X., Nakano K., Nomura M., Chiba N. and Nishimura O. (2007), A thermodynamic analysis on adsorption of estrogens in activated sludge process, Water Research, 41(11), 2341-2348.

Sarafraz S., Khani M.and Yaghmaeian K. (2007), Quality and quantity survey of hospital wastewaters in Hormozgan province, Iranian Journal of Environmental Health Science and Engineering, 4(1), 43-50.

Servos M.R., Bennie D.T., Burnison B.K., Mclnnis R., Neheli T., Schnell A., Seto P., Smyth S.A. and Ternes T.A. (2005), Distribution of estrogens, $17 \beta$-estradiol and estrone, in Canadian municipal wastewater treatment plants, Science of the Total Environment, 336(1-3), 155-170.

Silva C.P., Lima D.L.D., Schneider R.J., Otero M. and Esteves V.I. (2013), Development of ELISA methodologies for the direct determination of $17 \beta$-estradiol and $17 \alpha$-ethinylestradiol in complex aqueous matrices, Journal of Environmental Management, 124, 121-127.

Suarez S., Lema J.M. and Omil F. (2009), Pre-treatment of hospital wastewater by coagulation-flocculation and flotation, Bioresource Technology, 100(7), 2138-2146.

Sun W. and Zhou K. (2014), Adsorption of $17 \beta$-estradiol by multi-walled carbon nanotubes in natural waters with or without aquatic colloids, Chemical Engineering Journal, 258, 185-193.

Tanaka H., Yakou Y., Takahashi A., Higashitani T. and Komori K. (2001), Comparison between estrogenicities estimated from DNA recombinant yeastassay and from chemical analyses of endocrine disruptors during sewage treatment, Water Science and Technology, 43(2), 125-132. 
Ternes T.A., Stumpf M., Mueller J., Haberer K., Wilken R.-D and Servos M. (1999), Behavior and occurrence of estrogens in municipal sewage treatment plants-I. Investigations in Germany, Canada and Brazil, Science of the Total Environment, 225(1), 81-90.

Tilton F., Benson W.H.and Schlenk D. (2002), Evaluation of estrogenic activity from a municipal wastewater treatment plant with predominantly domestic input, Aquatic Toxicology, 61, 3, 211-224.

Tyler C., Spary C., Gibson R., Santos E.M., Shears J. and Hill E.M. (2005), Accounting for differences in estrogenic responses in rainbow trout (Oncorhynchus mykiss: Salmonidae) and roach (Rutilus rutilus: Cyprinidae) exposed to effluents from wastewater treatment works, Environmental Science and Technology, 39(8), 2599-2607.

US.EPA. (2014, November 17). Contaminant Candidate List 3 - CCL 3. Retrieved from http://www2.epa.gov/ccl/contaminant-candidate-list-3-ccl-3

Writer J.H., Ryan J.N., Keefe S.H. and Barber L.B. (2011), Fate of 4-nonylphenol and 17 $\beta$-estradiol in the Redwood River of Minnesota, Environmental Science and Technology, 46(2), 860-868.

Ying G.-G., Kookana R.S., Kumar A. and Mortimer M. (2009), Occurrence and implications of estrogens and xenoestrogens in sewage effluents and receiving waters from South East Queensland, Science of the Total Environment, 407(18), 5147-5155.

Yuan X., Tianyuan L., Zhou L. and Zhao X. (2014), Characteristics and Risk Assessment of Estrogenic Compounds in Rivers of Southern Jiangsu Province, China, IERI Procedia, 9, 176-184.

Zhang A., Li Y.and Chen L. (2014), Distribution and seasonal variation of estrogenic endocrine disrupting compounds, $\mathrm{N}$-nitrosodimethylamine, and N-nitrosodimethylamine formation potential in the Huangpu River, China, Journal of Environmental Sciences, 26(5), 1023-1033.

Zhao L., Li Z., Ying X. (2006), Development of a highly sensitive, second antibody format chemiluminescence enzyme immunoassay for the determination of 17ß-estradiol in wastewater, Analytica Chimica Acta, 558(1), 290-295. 